\title{
PERSEPSI NILAI MEWAH PADA KONSUMEN TAS BRANDED: KAJIAN NILAI BUDAYA DI INDONESIA
}

\author{
Mutiara Tioni Asprilia ${ }^{1^{*}}$, Azhar El Hami ${ }^{1}$ \\ ${ }^{1}$ Fakultas Psikologi, Universitas Padjadjaran, Bandung 45363, Indonesia
}

*Email: mutiara13006@mail.unpad.ac.id

\begin{abstract}
Abstrak
Mayoritas konsumen di Indonesia membeli produk mewah untuk meningkatkan kualitas diri dan status sosial. Penelitian ini bertujuan untuk mengidentifikasi dimensi nilai finansial, fungsional, individual, dan sosial yang muncul sebagai nilai dominan dalam mempersepsi nilai mewah. Penelitian ini menggunakan desain cross sectional study dengan pendekatan kuantitatif. Partisipan yang terlibat dalam penelitian ini sebanyak 120 pengguna tas branded di Indonesia yang didapat menggunakan teknik snowball sampling. Hasil penelitian disajikan secara deskriptif dan dikaji lebih lanjut untuk mengetahui perbedaan pola konsumsi produk mewah di Indonesia berdasarkan nilai budaya. Hasil penelitian menunjukkan tiga budaya terbesar yang menggunakan tas branded di Indonesia merupakan suku Jawa, Sunda, dan Minangkabau. Berdasarkan ketiga budaya tersebut, nilai finansial merupakan nilai dominan dalam membentuk persepsi nilai mewah. Nilai dominan yang membentuk persepsi nilai mewah memiliki pola serupa pada budaya Jawa dan Minangkabau. Budaya Jawa dan Minangkabau menunjukkan nilai dominan pada nilai finansial yang diikuti dengan nilai fungsional, individual, dan sosial secara berurutan. Perbedaan pola terlihat pada budaya Sunda dengan nilai dominan pada nilai finansial yang diikuti dengan nilai sosial, fungsional, dan individual secara berurutan. Hasil penelitian ini dapat digunakan untuk membantu strategi pemasaran yang lebih spesifik dan sensitif terhadap kebutuhan konsumen.
\end{abstract}

Kata kunci: nilai budaya, perilaku konsumen, persepsi nilai mewah, psikologi konsumen, tas branded

\section{Luxury Value Perception in Branded Bag Consumer: A Review of Indonesian Cultural Value}

\begin{abstract}
Majority of Indonesian consumers purchase luxury products to increase their self-quality and social status. This study aimed to identify the financial, functional, individual, and social value dimension which emerge as dominant value in perceiving luxury value. The participants involved in this study were 120 users of branded bags in Indonesia obtained using the snowball sampling technique. Results were reported in descriptive manner and further discussed regarding the consumption pattern of luxury goods in Indonesia based on cultural value. Result showed that major ethnic groups in Indonesia that used branded bag were Javanese, Sundanese, and Minangkabau. From these ethnic groups, financial dimension was the dominant consideration in forming luxury value perception. Dominant value that shapes luxury value perception has similar pattern ini Javanese and Minangkabau culture. Javanese and Minangkabau culture showed dominant value in financial value, followed by functional, individual, and social value respectively. Difference in pattern were shown in Sundanese culture with dominant value in financial value, followed by social, functional, and individual value respectively. Information from results can be used to achieve a more specific and sensitive marketing strategy towards consumer's needs.
\end{abstract}

Keywords: branded bag, consumer behavior, consumer psychology, cultural value, luxury value perception

\section{PENDAHULUAN}

Industri mode saat ini berpengaruh secara signifikan dalam perkembangan ekonomi dunia. Suatu negara yang memiliki industri mode dikatakan mempunyai kesempatan untuk memperoleh momentum dalam menjadi negara berkembang (Linden, 2016). Dalam industri ini, terdapat produk mode yang diproduksi secara massal untuk memenuhi kebutuhan dasar dan terdapat pula produk yang diproduksi dengan kualitas terjaga. Produk yang diproduksi secara terjaga ini merupakan produk-produk yang umumnya diberi harga lebih mahal sehingga menjadi produk mewah. Produk mewah secara umum merupakan barang yang dianggap paling tinggi tingkatannya dalam hal kualitas dan harga. Salah satu contohnya adalah merek mode mewah yang secara global dianggap paling bernilai pada tahun 2020, yaitu Louis Vuitton (SRD, 2020) dengan nilai 51,8 miliar 
USD dan berada pada tingkat ke-19 di antara merek dunia lainnya dari semua sektor (Kapferer, 2016). Sebagai merek mewah paling bernilai di dunia, Louis Vuitton juga merupakan salah satu merek mode mewah yang paling digemari di Indonesia, sebagaimana dinyatakan oleh penelitian pasar barang mewah bahwa perusahaan Moët Hennessy Louis Vuitton (LVMH) mendominasi sebesar 30 persen dari keseluruhan penjualan produk mewah (SRD, 2020).

Indonesia telah menjadi prioritas bagi banyak merek mewah dikarenakan perkembangan pesat konsumen yang mampu membeli produk mewah. Merujuk pada data BPS (2020), terdapat peningkatan pesat jumlah penduduk dengan pendapatan kelas menengah. Selain itu, data pendapatan dari penjualan produk mewah di Indonesia mencapai 2.035.000.000 USD (SRD, 2020). Perkembangan ekonomi kapitalis yang cepat di Indonesia menjadikan gengsi dan status suatu nilai yang bergantung sepenuhnya pada gaya hidup seseorang berikut pola konsumsinya. Seseorang membeli dan mengonsumsi yang dipercayai bernilai tinggi sehingga ini menjadi salah satu pendorong keputusan membeli. Dalam mengonsumsi produk yang digunakan seharihari, umumnya harga yang bersedia dibayar disesuaikan dengan yang diperoleh. Namun, hal ini sedikit berbeda dengan produk mewah. Saat membeli produk mewah dengan harga yang tinggi, konsumen tidak hanya mendapatkan kegunaannya namun juga kepuasan pribadi dan status sosial (Heine, 2012). Selain fungsi, merek mewah juga menjual hedonisme, gaya, pengakuan, dan seni (Hagtvedt \& Patrick, 2009) dari barang yang diproduksinya. Penelitian yang dilakukan oleh Shukla (2015) terhadap 900 konsumen produk mewah menunjukkan bahwa mayoritas konsumen di Indonesia membeli produk mewah untuk meningkatkan kualitas diri melalui perilaku konsumsi.

Selain itu, konsumen produk mewah di Indonesia juga menikmati pengalaman membeli produk tersebut karena terkadang dianggap mampu menjadi distraksi dari permasalahan hidup mereka. Penelitian Asprilia (2017) terhadap 225 orang pengguna produk mode mewah di wilayah Jakarta dan Bandung mengungkapkan, alasan utama konsumen membeli dan menggunakan barang mewah di antaranya adalah karena produk nyaman digunakan, terdapat perasaan berbeda saat menggunakan produk, dan terdapat perasaan superior ketika menggunakan produk mewah. Selain itu, para konsumen tersebut juga menyatakan setuju bahwa produk-produk mewah memengaruhi gaya hidup mereka secara keseluruhan.

Dibalik kebersediaan konsumen untuk membayar harga yang mahal saat membeli produk mewah, terdapat persepsi mengenai nilai mewah yang melatarbelakanginya. Merek mewah bukan hanya menjual produk, namun juga citra mewah yang menempel sebagai kepribadian dari nama merek tersebut (Kapferer, 2016). Foushee, Remy, dan Schmidt (2015) menemukan bahwa pembentukan nilai mewah pada perusahaan-perusahaan merek mewah separuhnya didapat dari pencapaian performa yang superior dan separuh lainnya didapat dari membentuk persepsi konsumen. Selain melalui strategi pemasaran tradisional, saat ini pemasaran dilakukan secara digital. Aktivitas ini khususnya memengaruhi banyak populasi muda yang memiliki presensi daring kuat (Buchanan et al., 2018). Populasi muda di Indonesia dapat sangat mudah terpengaruh oleh mimpi-mimpi yang diciptakan oleh media sehingga mereka rela mengerahkan energi dan uang untuk menggunakan merek ternama. Persepsi merupakan hal yang berperan penting dalam munculnya perilaku seseorang. Kebutuhan seseorang akan produk mewah tercipta dari persepsi mengenai nilai suatu produk mewah atau disebut juga Luxury Value Perception (LVP). LVP terbentuk dari empat dimensi nilai yaitu dimensi nilai finansial, fungsional, individual, dan sosial (Wiedmann, Hennigs, \& Siebels, 2009). Dimensi nilai finansial ditunjukkan dengan hal-hal yang berkaitan dengan moneter dari suatu produk seperti harga. Dimensi nilai fungsional berkaitan dengan kegunaan dari produk itu sendiri. Dimensi nilai individual ditunjukkan dengan kesesuaian produk dengan diri konsumen. Dimensi sosial ditunjukkan dengan kebutuhan untuk menyesuaikan diri dan memperoleh posisi di lingkungan.

Penggunaan sumber daya material dengan persepsi akan suatu tingkatan tertentu dapat membentuk kelas sosial (Kraus et al., \& Keltner, 2012). Penggunaan produk mewah dalam hal ini dapat membantu seseorang untuk masuk ke dalam kelas sosial tertentu. Lebih lanjut, membentuk suatu kelas dan gaya hidup bukan hanya bergantung pada pribadi namun juga pada lingkungan sehingga tercipta identitas yang kolektif. Masyarakat Indonesia menunjukkan kesadaran berkelas, terutama yang ditentukan oleh keanggotaan pada suatu kelompok dengan gaya hidup tertentu (Ansori, 2009). Adanya kesadaran sosial pada masyarakat Indonesia terkait esensi suatu 
merek mewah, informasi demografi, dan psikografik berperan penting dalam menentukan perilaku mengonsumsi suatu barang (Mullen \& Johnson, 2013). Sebagai contoh, konsumen di India yang perilaku konsumsinya sangat dipengaruhi oleh pendapat lingkungan memiliki perbedaan nilai dengan konsumen di Indonesia yang meskipun menganut nilai kolektivis, perilaku konsumsinya tetap lebih banyak didasarkan pada kepuasan diri sendiri dibandingkan dengan pendapat lingkungan (Shukla, 2015).

Yakup, Mucahit, dan Reyhan (2011) menjelaskan bahwa dalam membuat keputusan konsumsi, faktor budaya yang meliputi kepercayaan dan tradisi memiliki posisi signifikan, kemudian diikuti dengan faktor lingkungan meliputi teman dan kelompok sosial. Dalam menentukan perilaku konsumsi, seseorang dipengaruhi oleh faktor internal dan faktor eksternal. Salah satu faktor eksternal yang menentukan keinginan dan perilaku konsumen yang paling mendasar adalah budaya (Budiman, 1997). Budaya dapat memengaruhi penilaian konsumen terhadap suatu produk sehingga penting untuk memperhatikan faktor demografi tersebut dalam pembentukan persepsi nilai mewah. Budaya memiliki pengaruh terhadap cara berpikir karena sifatnya yang menyeluruh, misalnya suku tertentu menyukai cita rasa manis atau pedas sehingga menentukan keputusan memilih makanan dan batasan norma yang dibuatnya (Budiman, 1997). Secara tidak disadari, budaya yang tidak secara langsung mengintervensi perilaku konsumsi seseorang merupakan faktor paling dasar yang menentukan keinginan dan pemuasan kebutuhan konsumen.

Asprilia (2017) serta Candra dan Abadi (2018) menemukan hasil serupa terkait pembentukan LVP. Persepsi nilai finansial dan fungsional merupakan persepsi nilai dominan pada pengguna produk mewah di Indonesia, sedangkan persepsi nilai individual dan sosial tidak memiliki pengaruh yang signifikan terhadap intensi membeli produk mode mewah. Berdasarkan penelitian tersebut, telah diperoleh peranan masing-masing dimensi nilai terhadap LVP pada pengguna produk mewah secara umum. Meski demikian, hasil penelitian masih perlu dikaitkan lebih lanjut dengan faktor demografi ataupun psikografi yang dinyatakan memiliki kontribusi signifikan terhadap perilaku konsumen. Beberapa penelitian menunjukkan bahwa faktor demografi memiliki pengaruh yang signifikan terhadap pembentukan LVP, yang mana hal ini juga memengaruhi keputusan untuk membeli (Mentari \& Armia, 2016). Pada penelitian Ghoni dan Bodroastuti (2012), Mayasari dan Viadi (2017), serta Santoso dan Purwanti (2013) ditemukan bahwa faktor budaya, sosial, pribadi, dan psikologis secara signifikan memiliki pengaruh terhadap perilaku konsumen. Pentingnya pengaruh faktor demografi yang meliputi budaya, terutama di Indonesia dengan keberagaman budaya yang luas, menjadikan pembahasan kontribusi keragaman budaya terhadap pembentukan LVP atau pola konsumsi produk mewah di Indonesia suatu topik yang penting dalam upaha memperoleh gambaran LVP konsumen di Indonesia secara mendalam. Penelitian ini menjadi menarik dan berbeda dibandingkan penelitian mengenai LVP lainnya karena belum ada yang secara spesifik menekankan pembahasan akan nilai yang dianut oleh suatu budaya tertentu di Indonesia terkait pola persepsi terhadap produk mewah yang ditemukan, khususnya dalam penelitian ini akan dibahas dalam konteks budaya Jawa, Sunda, dan Minangkabau.

Penelitian ini bertujuan untuk mengidentifikasi dimensi nilai finansial, fungsional, individual, dan sosial yang muncul sebagai nilai dominan dalam pembentukan LVP. Data tersebut kemudian akan dikaji berdasarkan nilai budaya dari penggunanya. Melalui penelitian ini, diharapkan dapat diperoleh perbedaan pola dasar dan alasan individual dalam konsumsi produk mewah pada konsumen dengan budaya yang berbeda di Indonesia.

\section{METODE}

Penelitian ini menggunakan metode noneksperimental dengan desain cross-sectional study. Pengambilan data dilakukan secara daring pada akhir tahun 2017. Populasi pada penelitian ini adalah pengguna tas branded dengan karakteristik pernah menggunakan dan memiliki tas branded asli. Sampel diperoleh dengan menggunakan teknik snowball sampling. Teknik tersebut dipilih dengan mempertimbangkan jangkauan unit populasi yang sulit diidentifikasi dan tidak tersedia data lengkap mengenai anggota populasi. Melalui teknik sampling tersebut, sampel dijaring melalui koneksi dan komunitas pengguna tas branded.

Penelitian dilakukan pada 120 orang pengguna tas branded. Sebelum pengisian kuesioner, partisipan telah menyatakan kesediaannya untuk berpartisipasi. Sumber data dalam penelitian ini merupakan sumber data primer yang diperoleh melalui metode survei 
menggunakan kuesioner. Kuesioner LVP diadaptasi dari model LVP Wiedmann et al. (2009) yang menghubungkan penelitianpenelitian mengenai kemewahan menggunakan Teori Kapital serta framework lima dimensi (Vigneron \& Johnson, 2004) ke dalam empat dimensi LVP. Dalam penelitian ini, LVP memiliki definisi operasional yaitu cara seseorang mempersepsi nilai mewah yang ditunjukkan dengan nilai dominan di antara dimensi nilai finansial, fungsional, individual, dan sosial. Nilai finansial merupakan nilai yang berfokus pada aspek moneter. Nilai fungsional merupakan nilai yang berfokus pada fungsi dasar dari produk. Nilai individual merupakan nilai yang berfokus pada orientasi personal konsumen terhadap konsumsi produk mewah. Nilai sosial merupakan nilai yang berfokus pada produk atau jasa yang dirasakan dapat diakui di dalam kelompok sosial seseorang (Vigneron \& Johnson, 2004).

Kuesioner diadaptasi dengan cara melakukan translasi dari Bahasa Inggris ke dalam Bahasa Indonesia dan dilakukan penyesuaian budaya terhadap butir-butir pernyataan. Kuesioner yang telah diadaptasi kemudian diujicobakan pada pengguna tas branded. Untuk melihat validitas dari konten, hasil uji coba dikonsultasikan pada ahli. Kuesioner akhir terdiri atas 23 butir pernyataan dan menggunakan skala Likert dengan lima pilihan jawaban, skala 1 yang berarti sangat tidak setuju sampai dengan 5 yang berarti sangat setuju. Instrumen adaptasi LVP ditemukan memiliki konsistensi internal yang baik dan reliabel dengan nilai Cronbach's alpha $(\alpha)=0,913$. Data diolah dengan cara melakukan perbandingan skor pada setiap dimensi yang telah dikonversikan ke dalam weighted score. Semakin besar angka weighted score, semakin tinggi nilai dimensi tersebut. Dimensi dengan weighted score paling tinggi menunjukkan dimensi yang paling dominan atau paling dipertimbangkan dalam membentuk LVP secara keseluruhan.

Untuk menganalisis data secara deskriptif dan melihat pola persebaran data partisipan, digunakan aplikasi Microsoft Excel sebagai alat bantu. Analisis data secara deskriptif univariat bertujuan untuk menjabarkan fitur-fitur utama dan persebaran dari data yang telah diperoleh secara kuantitatif, dalam hal ini ingin dilihat pola dari nilai yang membentuk LVP. Hasil dari pengolahan data LVP dikaji lebih dalam berdasarkan nilai budaya di Indonesia. Nilainilai budaya memiliki tiga unsur yaitu keyakinan yang dipegang secara luas, aspek yang dikehendaki oleh budaya, dan dampak aktivitasnya ketika melanggar norma (Budiman, 1997). Oleh karena itu, penting untuk menganalisis data LVP dalam rangka melihat peranan nilai budaya tertentu di dalamnya dengan didasari oleh ketiga unsur tersebut. Unsur pertama, keyakinan yang dipegang secara luas dapat dilihat dari dalam budaya tertentu dan tercermin oleh perilaku individunya. Unsur kedua, aspek yang dikehendaki oleh budaya, dapat dilihat dari nilai-nilai yang dipegang teguh oleh budaya tertentu. Unsur ketiga, dampak aktivitasnya dapat dilihat melalui penerapan sanksi bagi individu yang dianggap melanggar norma budaya. Secara umum, dengan menganalisis data melalui ketiga unsur tersebut, perbedaan pola nilai, perilaku, dan dampak pada budaya yang berbeda dapat terlihat terutama dalam konteks produk mode mewah. Selain itu, dapat dilihat pula interaksi antara nilai, perilaku, dan dampak satu budaya dengan yang lainnya sehingga memunculkan pola LVP tertentu pada budaya yang berbeda.

\section{HASIL}

\section{Karakteristik Partisipan}

Pendapatan Keluarga. Partisipan dalam penelitian ini menunjukkan keberagaman pendapatan dimulai dari pendapatan sebesar Rp8.000.000,00 hingga lebih dari Rp100.000.000,00 setiap bulan. Mayoritas pengguna tas branded memiliki pendapatan di antara Rp8.000.000,00 hingga Rp20.000.000,00 per bulan, diikuti dengan partisipan yang memiliki pendapatan dari Rp20.000.000,00 hingga Rp100.000.000,00. Data ini menunjukkan bahwa pengguna tas branded setidaknya memiliki status sosial ekonomi menengah ke atas, dengan pendapatan bulanan minimum sebesar Rp8.000.000,00 pada kelompok konsumen kelompok menengah elite yang sedang meningkat dan berkembang terutama dalam pasar barang mewah di Indonesia, mengubah pasar merek mewah yang utamanya ditujukan pada segmen atas.

Pendidikan. Selain dilihat dari pendapatan, kelas sosial seseorang juga dapat dicerminkan oleh tingkat pendidikan. Hasil penelitian ini mengungkapkan, rentang pendidikan terakhir pengguna tas branded beragam mulai dari jenjang Sekolah Menengah Atas (SMA) hingga strata 3. Mayoritas partisipan yaitu sebesar 48 persen memiliki pendidikan terakhir S1 yang termasuk ke dalam jenjang pendidikan tinggi di Indonesia. 


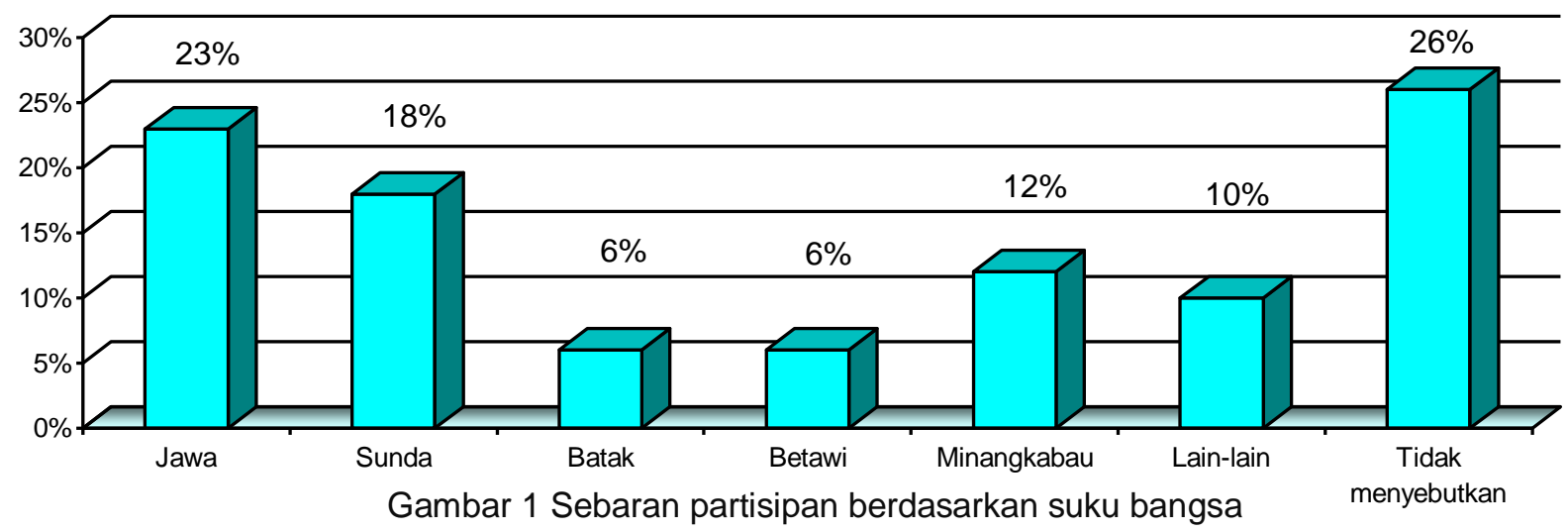

Suku Bangsa. Berdasarkan data yang diperoleh, sebaran suku partisipan pada penelitian ini disajikan pada Gambar 1. Apabila mengabaikan partisipan yang tidak menyebutkan suku bangsanya, mayoritas pengguna tas branded dalam penelitian ini berasal dari suku Jawa, Sunda, dan Minangkabau. Berdasarkan ketiga budaya mayoritas ini, data LVP selanjutnya dikaji berdasarkan nilai budaya dari ketiga suku tersebut.

\section{Luxury Value Perception (LVP)}

Data yang diperoleh melalui kuesioner LVP dianalisis dengan melakukan konversi data mentah ke dalam weighted score pada setiap dimensi sehingga skor pada masing-masing dimensi memiliki nilai yang setara satu dengan yang lain. Secara umum, kebanyakan partisipan pengguna tas merek branded di Indonesia $(61,10 \%)$ mempersepsikan dimensi nilai finansial sebagai nilai dominan yang membentuk LVP mereka terhadap suatu produk mewah (Gambar 2) yang mengacu pada aspek moneter dari produk tersebut.

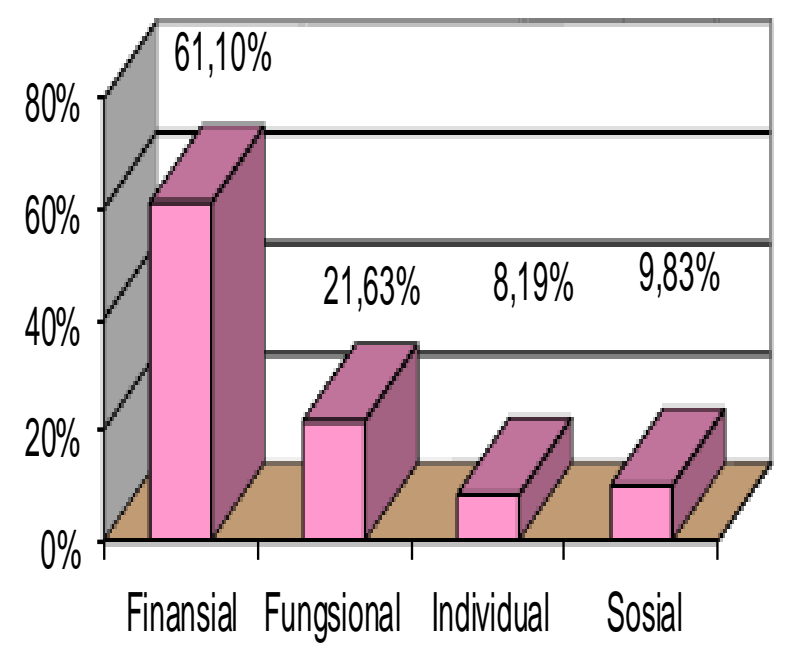

Gambar 2 Persentase dimensi LVP
Dimensi Nilai Finansial. Dimensi nilai finansial menggambarkan persepsi konsumen terhadap nilai moneter dari produk seperti harga. Konsumen mempertimbangkan nilai yang mereka korbankan untuk memperoleh suatu produk memberikan imbalan yang sesuai. Seseorang dengan nilai dominan pada aspek finansial dapat mempersepsikan pembelian produk mewah sebagai bentuk investasi yang menjamin kualitas dengan harga tinggi. Jika melihat kelas sosial dari partisipan dengan nilai dominan finansial, partisipan dengan pendapatan sebesar delapan hingga dua puluh juta rupiah per bulan menempati posisi tertinggi $(30 \%)$, sementara partisipan dengan pendapatan di atas seratus juta rupiah per bulan menduduki posisi terendah $(11,43 \%)$. Hal ini menunjukkan bahwa faktor finansial lebih banyak membentuk LVP konsumen dengan pendapatan yang lebih terbatas. Jika melihat pada butir pengukuran dimensi nilai finansial, partisipan memberikan nilai yang tinggi pada butir pernyataan yang menyebutkan bahwa harga dari tas branded merupakan indikator dari kualitas tas tersebut.

Dimensi Nilai Fungsional. Dimensi nilai fungsional menggambarkan persepsi konsumen terhadap kebergunaan dasar dari produk dan keuntungan menggunakan produk tersebut, seperti kualitas yang didapatkan, keunikan dari produk, kebergunaan, serta ketahanan dari produk itu sendiri. Seseorang dengan nilai dominan pada aspek fungsional dapat mempersepsikan pembelian produk mewah sebagai bentuk memenuhi kebutuhannya, dalam hal ini bisa dalam aspek mode ataupun fungsi tas. Jika melihat kelas sosial dari partisipan dengan nilai dominan fungsional, partisipan dengan pendapatan sebesar dua puluh hingga lima puluh juta rupiah per bulan menempati posisi tertinggi $(34,78 \%)$, dengan partisipan yang memiliki pendapatan di atas seratus juta rupiah dan di bawah delapan juta rupiah per bulan menduduki posisi terendah (8,7\%). Hal ini 
dapat menunjukkan bahwa faktor fungsional lebih banyak membentuk LVP konsumen dengan pendapatan menengah ke atas dan bukan merupakan pembentuk nilai dominan pada konsumen dengan pendapatan lebih rendah ataupun sangat tinggi. Jika melihat pada butir pengukuran dimensi nilai fungsional, butir- butir yang diberikan nilai lebih tinggi oleh partisipan menyebutkan bahwa kualitas dan ketahanan dari tas branded merupakan hal yang membuat konsumen tertarik untuk menggunakan tas tersebut.

Dimensi Nilai Individual. Dimensi ini menggambarkan persepsi konsumen terhadap kesesuaian produk mewah dengan diri mereka sebagai individu. Konsumen mempertimbangkan orientasi personal dari konsumsi barang mewah dan lebih mengarah pada pandangan personal seperti materialisme. Seseorang dengan nilai dominan pada aspek individual dapat mempersepsikan pembelian produk mewah sebagai bentuk pemenuhan kebutuhan personal yang disesuaikan dengan nilai-nilai pribadi yang dipegang.

Jika melihat kelas sosial dari partisipan dengan nilai dominan individual, partisipan dengan pendapatan sebesar delapan juta hingga dua puluh juta rupiah per bulan menduduki posisi tertinggi $(57,14 \%)$. Data pada dimensi nilai individual ini menunjukkan bahwa faktor individual dominan tersebar di berbagai kelas sosial dalam membentuk LVP pada konsumen. Jika melihat pada butir pengukuran dimensi nilai fungsional, butir- butir yang diberikan nilai lebih tinggi oleh partisipan menyebutkan bahwa muncul perasaan bahagia ketika partisipan menggunakan tas branded.
Dimensi Nilai Sosial. Dimensi nilai sosial menggambarkan persepsi konsumen terhadap kesesuaian penggunaan produk mewah dengan lingkungan sosialnya. Konsumen menggunakan produk mewah sebagai fungsi sosial yang membuat mereka mendapatkan keuntungan dari kelompok sosialnya saat mengonsumsi produk. Seseorang dengan nilai dominan pada aspek sosial mempersepsikan pembelian produk mewah sebagai bentuk pemenuhan kebutuhan sosial melalui pembelian produk mewah yang memberikan mereka nilai bergengsi. Jika melihat kelas sosial dari partisipan dengan nilai dominan sosial, partisipan dengan pendapatan sebesar delapan hingga dua puluh juta rupiah per bulan menempati posisi tertinggi (33,33\%), sementara partisipan yang memiliki pendapatan di atas seratus juta rupiah per bulan sama sekali tidak menunjukkan dimensi nilai sosial sebagai nilai dominan dalam membentuk LVP. Hal ini dapat menunjukkan bahwa faktor sosial lebih banyak membentuk LVP konsumen dengan pendapatan terbatas dan bukan merupakan pembentuk nilai dominan pada konsumen dengan pendapatan sangat tinggi. Jika melihat pada butir pengukuran dimensi nilai sosial, partisipan memberikan nilai yang tinggi pada butir yang menyebutkan bahwa menggunakan tas branded memberikan gengsi dan nilai lebih di lingkungan tempat partisipan berada.

\section{Luxury Value Perception pada Suku Jawa, Sunda, dan Minangkabau}

Penelitian ini melihat pola dimensi nilai yang dominan dalam pembentukan LVP berdasarkan nilai budaya pada tiga suku bangsa paling dominan dari pengguna tas branded yaitu suku Jawa, Sunda, dan Minangkabau.

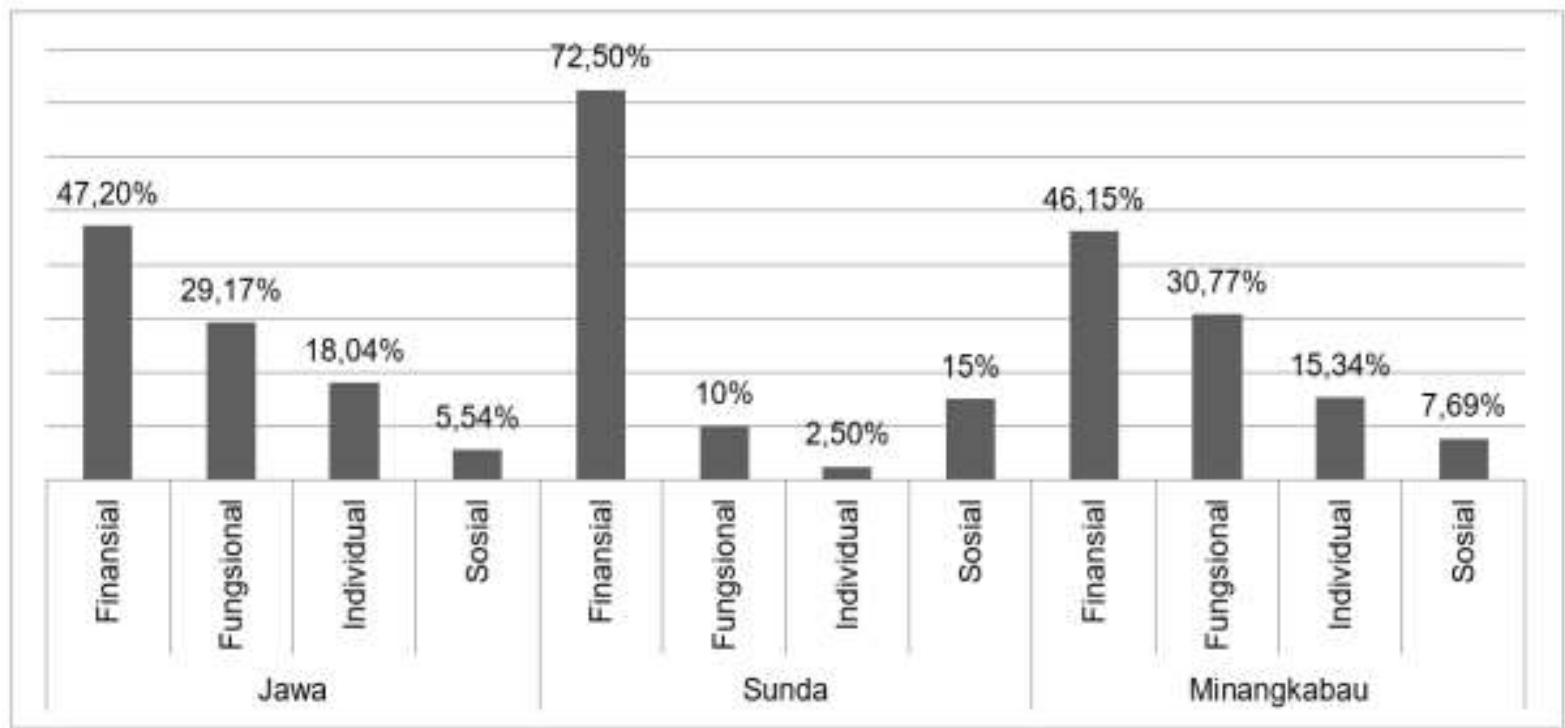

Gambar 3 Persentase dimensi nilai dominan LVP partisipan berdasarkan suku bangsa 
Cara memperoleh dimensi nilai dominan sama dengan cara memperoleh dimensi nilai dominan pada data secara umum, yaitu dengan memberikan ranking dimensi dari weighted score yang memiliki nilai tertinggi pada setiap partisipan. Dimensi nilai dengan nilai tertinggi dianggap sebagai nilai dominan. Pada Gambar 3 ditunjukkan dimensi nilai dominan yang membentuk LVP pada suku Jawa, Sunda, dan Minangkabau. Pola dimensi nilai dominan hampir mirip antar budaya, terutama budaya Jawa dan Minangkabau. Pada budaya Jawa dan Minangkabau, nilai finansial merupakan dimensi nilai dominan tertinggi dan sosial merupakan dimensi nilai dominan terendah. Sementara itu, pola dimensi nilai dominan terlihat agak berbeda pada budaya Sunda dimana nilai finansial sangat menonjol dan nilai individual berada pada posisi terendah.

\section{PEMBAHASAN}

Hasil dari penelitian ini menemukan bahwa dimensi nilai dominan yang membentuk LVP pada pengguna tas branded di Indonesia merupakan dimensi nilai finansial, sementara dimensi nilai pada urutan terendah merupakan dimensi nilai individual. Secara umum, data ini menunjukkan bahwa pola konsumsi produk mewah di Indonesia kebanyakan didasari oleh seberapa besar keuntungan yang didapatkan dari mengonsumsi produk dengan harga yang dibayarkan. Sebaliknya, kesesuaian nilai barang dengan nilai-nilai personal dari penggunanya di Indonesia kurang menjadi dasar seseorang mempersepsikan LVP dari suatu produk. Nilai di Indonesia ini sesuai dengan nilai yang mendasari pembelian produk mewah di Asia dimana konsumen produk mewah di Asia lebih sadar merek dalam membeli produk mewah apabila dibandingkan dengan konsumen Australia yang lebih mengacu pada nilai individual (Nayeem, 2012).

Konsumen yang sadar merek seperti konsumen di Indonesia lebih cenderung membeli produk mewah dari merek-merek yang sudah terpercaya dan memiliki harga yang umumnya lebih mahal. Hal ini dikarenakan produk yang sudah terkenal dapat dijadikan acuan atau indikator dari kualitas produk yang ditawarkan oleh merek tersebut (Forsythe, 1991). Status yang dimiliki suatu merek telah terbukti menjembatani konsumen yang sadar merek dengan kesediaan mereka untuk membayar harga premium untuk suatu produk (O'Cass \& Siahtiri, 2014). Di antara faktor yang memengaruhi perilaku membeli konsumen, salah satu faktor pentingnya adalah faktor ekonomi (Ramya \& Ali, 2016).
Faktor ekonomi dapat menentukan kelas sosial seseorang, yang mana melibatkan gaya hidup dalam hierarki sosial yang berbeda. Dalam hal ini, pendapatan memiliki kaitan yang erat dengan pengeluaran seseorang (Am \& Simanjuntak, 2020). Bagi kalangan menengah ke atas, keputusan membeli dipengaruhi oleh nilai pribadi dan sosial (Kautish, Khare, \& Sharma, 2020). Selain dilihat dari pendapatan, kelas sosial seseorang juga dapat dicerminkan oleh tingkat pendidikannya. Konsumen dengan tingkat pendidikan semakin tinggi umumnya semakin terdorong untuk bertindak dengan kesadaran yang lebih baik saat membuat keputusan konsumsi (Akpinar, Aykin, Sayin, \& Ozkan, 2009) agar dapat memenuhi apa yang dirasa menjadi kebutuhannya. Pada konsumen dengan tingkat pendidikan yang lebih tinggi, keputusan membeli lebih didasari oleh kesesuaian harga dan kegunaan dari barang (Asprilia, 2017).

Pola nilai dominan pada pengguna tas branded di Indonesia secara umum juga hampir serupa ketika data dilihat secara lebih spesifik berdasarkan beberapa suku bangsa di Indonesia, yaitu Jawa, Sunda, dan Minangkabau. Ketiga suku bangsa tersebut dirasa cukup representatif untuk menggambarkan penduduk di Indonesia apabila melihat data sensus pada tahun 2010 . Suku Jawa merupakan suku dengan jumlah terbesar di Indonesia, diikuti dengan suku Sunda (BPS, 2012). Suku Jawa dan Minangkabau menunjukkan pola nilai dominan yang hampir sama dan sedikit perbedaan pada suku Sunda.

Lebih lanjut, pola yang muncul pada suku Sunda dapat diinterpretasikan serupa dengan karakteristik konsumen produk mewah di Asia yang utamanya menentukan keputusan pembelian selain berdasarkan kesadaran akan merek yang dapat direpresentasikan oleh dimensi nilai finansial, namun juga dipengaruhi oleh pendapat bersama dari lingkungan sosial seperti keluarga atau teman (Forsythe, 1991) yang dalam LVP dapat direpresentasikan oleh dimensi nilai sosial. Hasil ini didukung dengan penemuan Auf, Meddour, Saoula, dan Majid (2018) bahwa keputusan konsumen untuk membeli berhubungan langsung dengan persepsi nilai budayanya.

Pada suku Jawa, nilai-nilai luhur dalam budayanya bersumber pada Serat Piwulang (Mumfangati, 2014) yang berisi (1) hidup sederhana dan melakukan apa yang disenangi; (2) kerja keras, hemat, dan mampu mengatur uang; dan (3) meningkatkan ilmu pengetahuan 
dan keterampilan. Nilai-nilai tersebut meliputi faktor psikologis, faktor ekonomi, dan faktor personal (Ramya \& Ali, 2016) dalam memengaruhi perilaku membeli konsumen. Apabila dikaitkan dengan hasil penelitian ini, nilai dominan finansial sesuai dengan nilai mengatur uang. Nilai fungsional mencerminkan masyarakat Jawa yang lebih mempertimbangkan kegunaan dari produk yang dikonsumsi daripada faktor pemenuhan kebutuhan psikologis dari suatu produk. Nilai individual mencerminkan ekspresi individu masyarakat Jawa untuk melakukan apa yang disenangi. Kekhasan dari data suku Jawa adalah nilai dominan sosial yang rendah. Apabila dikaitkan dengan nilai-nilai serat piwulang, hal ini sesuai karena nilai-nilai tersebut tidak terlalu menekankan pentingnya nilai sosial sebagaimana pada suku Sunda dan Minangkabau sehingga pada suku Jawa pengaruh sosial dan budaya dalam keputusan membeli tidak memiliki peran yang terlalu besar. Data pola komposisi dimensi nilai LVP pada konsumen suku Jawa mencerminkan nilai-nilai yang dianut oleh budaya Jawa, yaitu dapat mengatur pendapatan dan pengeluaran yang seimbang (Budiyono \& Feriandi, 2017).

Apabila melihat pada suku Sunda, selain didasari oleh nilai-nilai dari agama Islam, suku Sunda didasari oleh suatu pandangan utama (Suryani, 2011) yang berbunyi, "silih asah, silih asuh, silih asih." Istilah ini menggarisbawahi hubungan antar sesama manusia untuk saling mengajari, saling membimbing, dan saling mengasihi. Budaya Sunda menekankan pentingnya keharmonisan hubungan bermasyarakat tanpa melupakan jati diri masing-masing. Pandangan tersebut sangat terkait dengan faktor sosial dan budaya yang memengaruhi perilaku membeli konsumen sebagaimana dijelaskan Ramya dan Ali (2016). Selain dua pandangan falsafah yang merupakan kearifan lokal suku Sunda di atas, suku Sunda juga memiliki nilai-nilai dasar yang banyak ditemui dalam peribahasa Sunda yang meliputi: (1) berhubungan dengan Tuhan; (2) tanggung jawab, kedisiplinan dan kemandirian; (3) kejujuran; (4) hemat dan sopan santun; (5) kasih sayang, kepedulian, dan kerja sama; (6) percaya diri, kerja keras, kreatif, dan pantang menyerah; (7) keadilan dan kepemimpinan; (8) baik dan rendah hati; (9) toleransi, cinta damai, dan persatuan (Kodariah \& Gunardi, 2015).

Nilai-nilai ini selain terkait dengan faktor sosial dan budaya sebagaimana dua pandangan di atas, juga meliputi faktor personal dalam memengaruhi keputusan membeli (Ramya \& Ali, 2016). Apabila mengaitkan data LVP konsumen bersuku Sunda dengan nilai-nilai suku Sunda, mayoritas masyarakatnya mencerminkan nilai-nilai tanggung jawab dan hemat ketika membeli barang yang dirasa sesuai dengan harga yang dibayarkan. Kekhasan yang ditemukan pada suku Sunda apabila dibandingkan dengan hasil pada suku Jawa dan suku Minangkabau adalah pada nilai dominan sosial yang lebih tinggi.

Nilai dominan sosial mencerminkan bahwa suatu produk dipersepsikan mewah apabila produk tersebut diakui di dalam kelompok sosial mereka sebagai mencolok dan bergengsi (Wiedmann et al., 2009). Peran dari status sendiri adalah untuk mengomunikasikan informasi mengenai pemilik dari produk tersebut dan hubungan sosialnya (O'Cass \& Siahtiri, 2014). Hal ini sesuai dengan penekanan dalam suku Sunda mengenai hubungan sosial yang dianggap penting, namun tidak melupakan jati diri masing-masing anggotanya. Dengan nilai suku Sunda yang cukup menekankan pada lingkungan sosial, penerimaan dan pengakuan sosial juga menjadi penting sehingga hal ini menjadi suatu kebutuhan tersendiri ketika seorang anggota menempatkan dirinya di lingkungan tersebut. Kebutuhan ini kemudian tercermin dalam cara mereka mempersepsikan LVP yang sesuai dengan data dimensi nilai pembentuk LVP pada suku Sunda, yaitu dimensi nilai sosial sebagai nilai dominan setelah dimensi nilai finansial. Nilai ini digunakan sebagai dasar untuk membangun dan menjaga hubungan sesama masyarakat di dalam budaya Sunda (Hidayat \& Hafiar, 2019).

Pada suku Minangkabau, kebudayaannya didasari oleh adat dan agama Islam. Dalam hubungan individu dengan kelompoknya, masyarakat Minang memiliki sifat dasar kepemilikan (Rahmat, 2016), yaitu individu merupakan milik bersama kelompoknya dan kelompok adalah milik semua anggotanya. Suku Minangkabau menganut sifat-sifat yang dianggap ideal dalam menjalani hidup.

Sifat yang pertama merupakan "Hiduik Baraka, Baukua jo Bajangko (Sola, 2020).” Istilah ini memiliki arti "hidup berpikir, berukur, dan berjangka." Maksud dari pernyataan ini adalah untuk selalu memakai akal dalam bertindak, mempunyai rencana, dan perkiraan yang tepat. Dengan menggunakan akal, seseorang akan lebih waspada dan terencana serta terpikirkan dengan matang dalam perilakunya ke depan. Nilai ini sesuai dengan faktor personal dan ekonomi yang memengaruhi perilaku membeli konsumen (Ramya \& Ali, 2016). 
Sifat yang kedua adalah "Baso basi, malu jo sopan" yang artinya "sopan santun dan etika dalam pergaulan." Dalam adat Minang, budi pekerti yang baik menjadi ukuran martabat seseorang. Sifat yang penuh sopan santun dan beretika dalam pergaulan sehari-hari dianggap dapat menjauhkan seseorang dari permasalahan. Sifat ini terkait dengan faktor budaya yang memengaruhi perilaku membeli konsumen (Ramya \& Ali, 2016).

Sifat-sifat lainnya yang menjadi watak orang Minangkabau adalah tenggang rasa, setia, adil, hemat dan cermat, waspada, berani karena benar, arif-bijaksana-tanggap-sabar, rajin, dan rendah hati (Amir, 2001). Apabila mengaitkan data LVP pada suku Minangkabau dengan beberapa watak ideal pada suku ini (menggunakan akal, hemat, dan cermat), dapat dilihat keterkaitan tingginya dimensi finansial dan fungsional yang melatarbelakangi LVP pada suku Minangkabau. Nilai finansial mengacu pada aspek moneter yang harus ditukarkan dengan produk atau jasa, atau dengan kata lain seseorang harus menerima sesuai dengan apa yang dibayarkannya (Wiedmann et al., 2009), baik dalam bentuk kualitas barang maupun kepuasan psikologis lainnya. Nilai finansial yang menjadi nilai dominan pada suku Minangkabau ini sesuai dengan dasar nilai budaya Minangkabau yang menekankan hemat dan cermat serta perencanaan matang (Suseno, 2016).

Nilai dominan individual juga cukup banyak muncul sebagai pembentuk LVP suku Minangkabau. Nilai individual yang menyimbolkan ekspresi individu dapat terkait dengan watak orang Minang, yaitu berani karena benar. Berdasarkan nilai ini, suku Minangkabau tidak takut untuk menunjukkan dirinya selama tidak melanggar moral yang berlaku. Dengan kuatnya dasar-dasar yang menjunjung tinggi rasa kepemilikan, masyarakat Minang tidak terlalu menjunjung tinggi pentingnya mendapatkan pengakuan secara sosial dengan cara menjadi menonjol dalam komunitasnya.

Nilai tenggang rasa juga melatarbelakangi sifat orang Minang yang lebih memikirkan perasaan orang lain daripada berusaha mencapai suatu standar sosial tertentu untuk merasa lebih baik. Meski demikian, apabila dibandingkan dengan suku Jawa, nilai dominan sosial pada suku Minangkabau masih lebih tinggi. Data ini sesuai dengan nilai-nilai pada suku Minangkabau yang masih lebih menekankan pada aspek sosial serta mencerminkan keintiminan juga kedekatan dalam budaya Minangkabau
(Desyandri, 2015). Secara umum, baik suku Jawa, Sunda, maupun Minangkabau menunjukkan kesesuaian cerminan pola dimensi nilai dominan LVP dengan nilai yang dianut masing-masing budaya.

Perbedaan pola nilai dominan antar budaya yang ditemukan dari penelitian ini menguatkan teori yang telah ada bahwa budaya merupakan salah satu faktor dasar yang menentukan keinginan dan perilaku konsumsi seseorang (Ramya \& Ali, 2016). Meski demikian, penelitian lebih lanjut dengan karakteristik sampel dan jenis produk mewah yang berbeda dibutuhkan untuk memastikan bahwa hasil penelitian ini dapat digeneralisasikan terhadap seluruh konsumen produk mewah di Indonesia. Selain itu, penelitian lanjutan juga dapat diselenggarakan dengan melakukan uji hubungan serta lebih lanjut membahas aspek demografi dan psikografik lainnya yang mungkin memengaruhi persepsi konsumen akan nilai mewah sehingga pembahasan dapat lebih elaboratif.

\section{SIMPULAN DAN SARAN}

Dari penelitian ini ditemukan bahwa dimensi nilai yang mendominasi dalam pembentukan LVP pada suku Jawa, Sunda, dan Minangkabau adalah nilai finansial, fungsional, sosial, dan individual secara berurutan. Dalam nilai finansial sebagai nilai dominan, konsumen tas branded di Indonesia menganggap bahwa harga merupakan indikator dari kualitas suatu barang dan hal ini menjadi faktor kuat dalam seseorang mempersepsikan LVP. Apabila mengaitkan dengan nilai dari masing-masing budaya, perbedaan pola nilai dominan yang muncul sesuai dengan nilai yang dipegang oleh setiap suku.

Hasil dari penelitian ini dapat digunakan oleh praktisi serta pembuat kebijakan yang berkaitan dengan kegiatan jual-beli atau pemasaran dan bersinggungan dengan konsumen sebagai strategi pemasaran yang spesifik dan sensitif terhadap budaya tertentu. Dengan menerapkan strategi pemasaran yang spesifik di setiap area yang berbeda, konsumen dapat merasa lebih puas dengan pembelian produk dan penjualan dapat ditingkatkan. Informasi ini utamanya dapat dimanfaatkan oleh pengusaha produk mode lokal yang ingin memasarkan produknya di dalam negeri. Hasil penelitian juga dapat berguna sebagai sumbangan teoritis dalam bidang perilaku konsumen terkait hal-hal yang melatarbelakangi perilaku konsumen. Penelitian lebih lanjut dapat dilakukan terkait konsumsi atau persepsi terhadap barang mewah dengan 
ruang lingkup yang lebih luas seperti poduk selain produk mode atau pada merek mewah lain. Selain dalam aspek pemasaran, hasil kajian terkait nilai budaya dapat menjadi tambahan pengetahuan bagi konsumen agar melakukan pembelian secara bijak dengan menyadari faktor apa saja yang melatarbelakangi keputusan mereka membeli. Konsumen juga dapat lebih mempertimbangkan nilai-nilai budaya yang mungkin memengaruhi pola konsumsinya, terutama terhadap konsumsi produk mewah.

\section{DAFTAR PUSTAKA}

Akpinar, M. G., Aykin, S., Sayin, C., \& Ozkan, B. (2009). The role of demographic variables in purchasing decisions on fresh fruit and vegetables. Journal of Food Agriculture and Environment, 7(4), 106110.

Am, M. R., \& Simanjuntak, M. (2020). Nilai dan kontrol diri sebagai faktor pembentuk sikap dalam perilaku pembelian impulsif antargenerasi. Jurnal IImu Keluarga \& Konsumen, 13(3), 262-276. doi:10.24156/jikk.2020.13.3.262.

Amir, M. S. (2001). Adat Minangkabau: Pola dan tujuan hidup orang Minang. Jakarta, ID: PT Mutiara Sumber Widya.

Ansori, M. (2009). Consumerism and the emergence of a new middle class in globalizing Indonesia. Explorations: $A$ Graduate Student Journal of Southeast Asian Studies, 9(1), 87-97.

Asprilia, M. T. (2017). Studi deskriptif mengenai gambaran luxury value perception pada pengguna tas merek Louis Vuitton (Thesis). Bandung, ID: Universitas Padjadjaran.

Auf, M. A. A., Meddour, H., Saoula, O., \& Majid, A. H. (2018). Consumer buying behaviour: The roles of price, motivation, perceived culture importance, and religious orientation. Journal of Business and Retail Management Research, 12(4). doi:10.24052/JBRMR/V12IS04/ART-18.

[BPS] Badan Pusat Statistik. (2012). Kewarganegaraan Suku Bangsa Agama dan Bahasa Sehari-Hari Penduduk Indonesia. Jakarta, ID: BPS.

[BPS] Badan Pusat Statistik. (2020). Laporan Bulanan Data Sosial Ekonomi Januari 2020. Jakarta, ID: BPS.

Buchanan, L., Kelly, B., Yeatman, H., \&
Kariippanon, K. (2018). The effects of digital marketing of unhealthy commodities on young people: A systematic review. Nutrients, $10(2), \quad 148$. doi:10.3390/nu10020148.

Budiman, S. (1997). Pengaruh faktor kebudayaan terhadap keputusan pembelian oleh konsumen. Bina Ekonomi, 1(1), 36-42. doi:10.26593/be.v1i1.474.\%25p.

Budiyono, \& Feriandi, Y. A. (2017). Menggali nilai nilai kearifan lokal Budaya Jawa sebagai sumber pendidikan karakter. Madiun, ID: Universitas PGRI Madiun.

Candra, M., \& Abadi, F. (2018). The influence of value perceptions on purchase intention towards luxury fashion products in Jakarta. Jurnal Bina Manajemen, 6(2), 157-176.

Desyandri. (2015). Nilai-nilai edukatif lagu-lagu Minang untuk membangun karakter peserta didik. Jurnal Pembangunan Pendidikan: Fondasi dan Aplikasi, 3(2), 126-141. doi:10.21831/jppfa .v3i2.7566.

Forsythe, S. M. (1991). Effect of private, designer, and national brand names on shoppers' perception of apparel quality and price. Clothing and Textiles Research Journal, 9(2), 1-6. doi:10.1177/0887302X9100900201.

Foushee, S. N., Remy, N., \& Schmidt, J. (2015). Creating value in fashion: How to make the dream come true. Retrieved from https://www.mckinsey.com/businessfunctions/marketing-and-sales/ourinsights/creating-value-in-fashion-how-tomake-the-dream-come-true\#.

Ghoni, A., \& Bodroastuti, T. (2012). Pengaruh faktor budaya, sosial, pribadi dan psikologi terhadap perilaku konsumen: Studi pada pembelian rumah di perumahan Griya Utama Banjardowo Semarang. Jurnal Kajian Akuntansi dan Bisnis, 1(1). 1-23.

Hagtvedt, H., \& Patrick, V. (2009). The broad embrace of luxury: Hedonic potential as a driver of brand extendibility. Journal of Consumer Psychology, 19(4), 608-618. doi:10.1016/j.jcps.2009.05.007.

Heine, K. (2012). Concept of luxury brands. Retrieved from http://www.conceptofluxurybrands.com/con cept-of-luxury-\%0Abrands/definition-ofluxury-brands.

Hidayat, D., \& Hafiar, H. (2019). Nilai-nilai 
budaya soméah pada perilaku komunikasi masyarakat suku Sunda. Jurnal Kajian Komunikasi, 7(1). 84-96. doi:10.24198/jkk.v7i1.19595.

Kapferer, J. N. (2016). Beyond rarity: The paths of luxury desire, how luxury brands grow yet remain desirable). Journal of Product \& Brand Management, 25(2), 120-133. doi:10.1108/JPBM-09-2015-0988.

Kautish, P., Khare, A., \& Sharma, R. (2020). Influence of values, brand consciousness and behavioral intentions in predicting luxury fashion consumption. Journal of Product \& Brand Management, 29(7). doi:10.1108/JPBM-08-2019-2535.

Kodariah, S., \& Gunardi, G. (2015). Nilai kearifan lokal dalam peribahasa Sunda: Kajian semiotika. Patanjala, 7(1), 113-130. doi:10.30959/patanjala.v7i1.88.

Kraus, M. W., Piff, P. K., Mendoza-Denton, R., Rheinschmidt, M. L., \& Keltner, D. (2012). Social class, solipsism, and contextualism: How the rich are different from the poor. Psychological Review, 119(3), 546-572. doi:10.1037/a0028756.

Linden, A. R. (2016). An analysis of the fast fashion industry. Retrieved from https://digitalcommons.bard.edu/cgi/viewco ntent.cgi?referer $=\&$ httpsredir $=1 \&$ article $=10$ 33\&context=senproj_f2016.

Mayasari, I., \& Viadi, I. (2017). Purchasing massive prestige brands: The exploration of consumers' value perceptions. Asean Marketing Journal, 9(1), 1-17. doi:10.21002/amj.v9i1.4447.

Mentari, A., \& Armia, S. (2016). Pengaruh faktor demografi terhadap keputusan pembelian mobil di Kota Banda Aceh dengan persepsi merek mewah sebagai variabel mediasi. Jurnal IImiah Mahasiswa Ekonomi Manajemen, 1(1), 23-36. doi:10.24815/jimen.v1i1.31.

Mullen, B., \& Johnson, C. (2013). The psychology of consumer behavior. New York, US: Psychology Press.

Mumfangati, T. (2014). Nilai-nilai luhur dalam budaya Jawa, filosofi dan maknanya: Sebuah interpretasi dari sumber serat piwulang. Retrieved from https://kebudayaan.kemendikbud.go.id/bpn byogyakarta/2014/07/19/nilai-nilai-luhurdalam-budaya-jawa-filosofi-danmaknanya-sebuah-interpretasi-darisumber-serat-piwulang/
Nayeem, T. (2012). Cultural influences on consumer behaviour. International Journal of Business and Management, 7(21). doi:10.5539/ijbm.v7n21p78.

O'Cass, A., \& Siahtiri, V. (2014). Are young adult Chinese status and fashion clothing brand conscious. Journal of Fashion Marketing and Management, 18(3), 284300. doi:10.1108/JFMM-03-2012-0013.

Rahmat, W. (2016). Penerapan kaba Minangkabau sebagai media pelestarian bahasa amai (ibu) dan kesusastraan dalam pendidikan literasi di Minangkabau. Jurnal Ipteks Terapan, 10(4), 236-241. doi:10.22216/jit.2016.v10i4.579.

Ramya, N., \& Ali, S. M. (2016). Factors affecting consumer buying behavior. International Journal of Applied Research, 2(10), 76-80.

Santoso, D. T. T., \& Purwanti, E. (2013). Pengaruh faktor budaya, faktor sosial, faktor pribadi, dan faktor psikologis terhadap keputusan pembelian konsumen dalam memilih produk operator seluler Indosat-M3 di Kecamatan Pringapus Kab. Semarang. Jurnal Ilmiah among Makarti, 6(12), 112-129.

Shukla, P. (2015). Consumers in Asia buy luxuries for different reasons to the West. Retrieved from http://theconversation.com/consumers-inasia-\%0Abuy-luxuries-for-differentreasons-to-the-west-45069.

Sola, E. (2020). "Bundo kanduang" Minangkabau vs. kepemimpinan. Jurnal Sipakalebbi, 4(1), 346-359.

[SRD] Statistia Research Department. (2020). Luxury Goods Report 2020. Retrieved from https://www.statista.com/study /55494/luxury-goods-report/

[SRD] Statistia Research Department. (2020). Most Valuable Global Luxury Brands 2020. Retrieved from https://www.statista.com/statistics/267948/ brand-value-of-the-leading-10-mostvaluable-luxury-brands-worldwide/

Suryani, N. (2011). Ragam pesona budaya Sunda. Bogor, ID: Ghalia Indonesia.

Suseno, Y. P. W. (2016). Penggambaran identitas etnis Minang dalam film Tabula Rasa (Tesis). Surabaya, ID: Universitas Airlangga.

Vigneron, F., \& Johnson, L. W. (2004). 
Measuring perceptions of brand luxury. Journal of Brand Management, 11(6), 484-506. doi:10.1057/PALGRAVE.BM.2540194.

Wiedmann, K.-P., Hennigs, N., \& Siebels, A. (2009). Value-based segmentation of luxury consumption behavior. Psychology \& Marketing, 26(7), 625-651. doi:10.1002/mar.20292.
Yakup, D., Mucahit, C., \& Reyhan, O. (2011). The impact of cultural factors on the consumer buying behaviors examined through an impirical study. International Journal of Business and Social Science, 2(5), 109-114. doi:10.24297/ jssr.v2i2.3108. 